MATEC Web of Conferences 47. 05008 (2016)

DOI: $10.1051 /$ matecconf/20164705008

(C) Owned by the authors, published by EDP Sciences, 2016

\title{
Pollutants Characterization of Car Wash Wastewater
}

\author{
Nor Haslina Hashim ${ }^{1, a}$ and Nadzirah Zayadi $^{2}$ \\ ${ }^{1}$ Faculty of Engineering Technology, Universiti Tun Hussein Onn Malaysia, 86400 Batu Pahat, Johor, Malaysia \\ ${ }^{2}$ Faculty of Civil and Environmental Engineering, Universiti Tun Hussein Onn Malaysia, 86400 Batu Pahat, Johor, \\ Malaysia
}

\begin{abstract}
The huge quantity of water consumed per car during washing cars yields the untreated effluents discharged to the stormwater system. Wastewater samples from snow car wash and two full hand service car wash station were analyzed for $\mathrm{pH}$ and the presence of $\mathrm{PO}_{4}{ }^{3-}, \mathrm{TP}, \mathrm{O} \& \mathrm{G}$, alkalinity, TSS, $\mathrm{NO}_{3}^{-}, \mathrm{NO}_{2}^{-}, \mathrm{COD}$ and surfactant in accordance Standard Method of Water and Wastewater 2012. Two full hand wash service stations and one station of snow foam service were investigated in this study. Amongst the stations, snow foam car wash station indicates the highest concentration of $\mathrm{PO}_{4}{ }^{3-}, \mathrm{TP}, \mathrm{O} \& \mathrm{G}, \mathrm{TSS}, \mathrm{COD}$ and surfactant with the average value of $10.18 \pm 0.87 \mathrm{mg} / \mathrm{L}, 30.93 \pm 0.31 \mathrm{mg} / \mathrm{L}, 85.00 \pm 0.64 \mathrm{mg} / \mathrm{L} 325.0 \pm 0.6$ $\mathrm{mg} / \mathrm{L}, 485.0 \pm 0.3 \mathrm{mg} / \mathrm{L}$ and $54.00 \pm 2.50 \mathrm{mg} / \mathrm{L}$ as MBAS, respectively. Whereas, in parameters characterization in different stages throughout the car wash process, O\&G was found to be the highest in pre soak stage, $\mathrm{PO}_{4}{ }^{3-}$, TP, TSS and COD in washing stage and $\mathrm{NO}_{3}{ }^{-}$ and $\mathrm{NO}_{2}^{-}$in rinse stage. All parameters were compared to Environmental Quality (Industrial Effluent) Regulations, 2009. There is a strong need to study on the characterization of car wash water in order to suggest the suitable treatment need for this type of wastewater.
\end{abstract}

\section{Introduction}

A car wash is defined as a non-domestic installation for external cleaning of cars [1]. Car wash generates high amount of wastewater approximately 150 to 350 litres per day being released in environment. Car washing in the street consists of oil and grease leaking during engine washing, high suspended solids from brake linings, with sand and dust being washed away and trace amounts of surfactant which are hardly degraded in environment. Commonly, parts of cars such as engine block, intake manifold, and brake drums have exceeded permissible limit discharges of heavy metal including iron, copper, zinc, and lead [2]. All the accumulated sediments will flow to the gutter system and go into storm water system without undergo treatment. Hence, endangered the ecosystem when washes away to the drainage system, streams and to the receiving waters, leads to the increased environment pollution [3]. Malaysia have their own environmental quality regulations, but the regulation is seldom enforced to the car wash industry. Generally, public perceived that the wastewater from car washing is not severely contaminated compared with other industrial wastewaters [4]. Hence, little attention is given to the car wash industries [5]. Presents, Malaysia has increased in car volumes on the road together with the existing number of cars. It has boosted the car wash industry, leading to the increase in car wash service stations, particularly in rapid development and

\footnotetext{
${ }^{a}$ Corresponding author : haslina@uthm.edu.my
} 
high population of the focal point area. The aim of this study was to provide basic data required for the characteristics of car wash wastewater in Malaysia.

\section{Sampling Sites}

Three car wash stations with different type of washing were selected in two districts in Johor which are Parit Raja (a small town in Batu Pahat district) and Johor Bahru based on the geographical location and most common type of car wash industries in Malaysia. The type of washing, approximate number of washed cars and the volume of water used per washed car are tabulated in Table 1 below. All the information was obtained from the interviewing session with the car wash station owner. In full hand service, it required full labour intensive of cleaning, with desired amount of surfactant being applied with buckets full of water. While, in a snow foam car wash the cleaning processes required high amount foams of surfactant with high pressure trigger guns and hoses connected to a water pump (Figure 1). These three stations finally discharged the untreated wastewater to the drains downstream of a water bodies system (Figure 2).

Table 1. Operation time, number of washed car and volume of water used for car wash stations.

\begin{tabular}{|l|c|c|c|}
\cline { 2 - 4 } \multicolumn{1}{c|}{} & \multicolumn{3}{c|}{ Car Wash Station } \\
\cline { 2 - 4 } \multicolumn{1}{c|}{} & Parit Raja & Johor Bahru & Johor Bahru \\
\hline Location & Full hand service & Full hand service & Snow Foam \\
\hline Type & 12 & 24 & 24 \\
\hline $\begin{array}{l}\text { Operation time per day } \\
\text { (hours) }\end{array}$ & 50 & $100-150$ & $100-150$ \\
\hline $\begin{array}{l}\text { Approximate number of } \\
\text { washed cars per day (unit) }\end{array}$ & 40 & 67 & 120 \\
\hline $\begin{array}{l}\text { Average volume of water } \\
\text { used per car (L) }\end{array}$ & & \multicolumn{3}{c|}{} \\
\hline
\end{tabular}

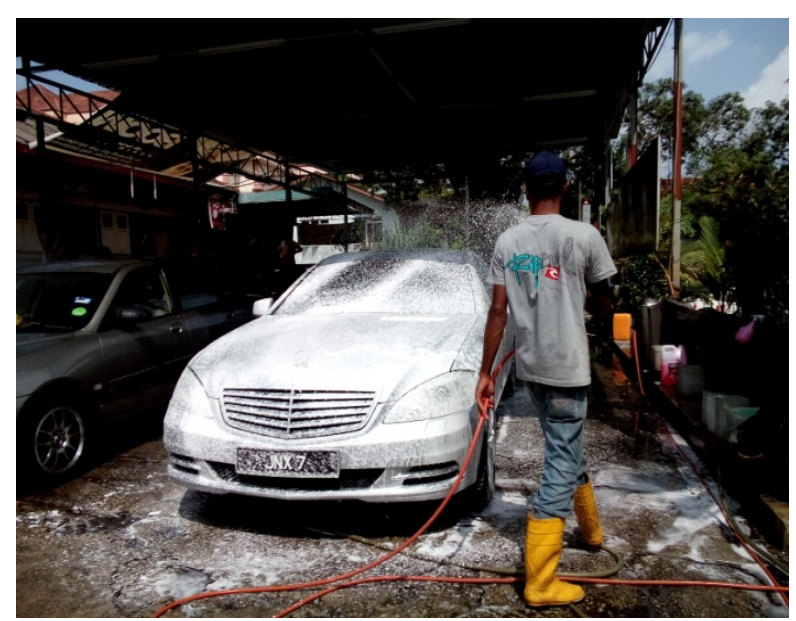

Figure 1. Snow car wash activity at Station 3.

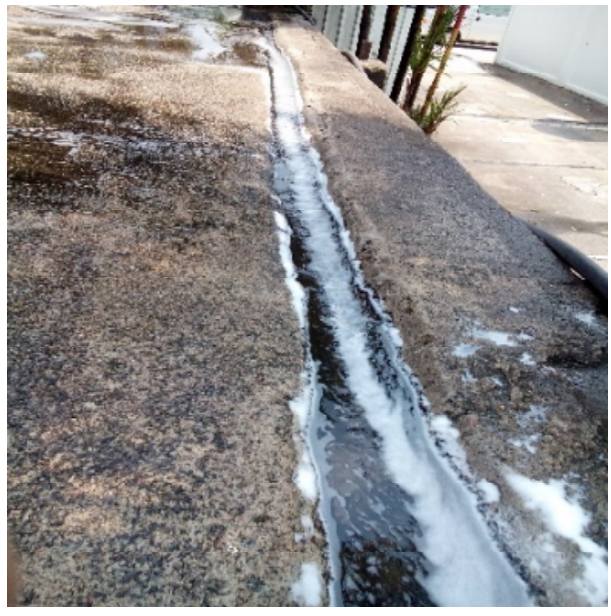

Figure 2. Outlet drainage of carwash wastewater. 


\section{Sampling Method}

Samples were collected for three car wash stations for 8 weeks. The samples were collected based on a composite samples collected when a car was being washed (approximately 1L per 5 minutes). Station 1 has better drainage system and different outlet for each washing processes, leads to the determination of pre-soak, wash and rinse stages. Pre-soak defined as the first process of car washes, where an amount of waters being applied during the exterior cleaning of cars before washing. The wash processes including of cleaning with surfactants was applied to wash away the dirts and grimes. Whereas, the rinse processes required washing proceses with clean water to remove the surfactants and dirts. The sample for each processes was differentiate and collected at the outlet point of drainage during the different stages were demonstrated. For Station 2 and Station 3, composite samples were obtained for three vehicles at same outlet, therefore the samples produced represent the whole presoak, wash and rinse stages. The sampling and sample preservation were based on Standard Methods for the Examination of Water and Wastewater (APHA, 2012) and stored at $4{ }^{\circ} \mathrm{C}$ until analysis.

\section{Analysis}

All parameters were measured in accordance Standard Method of Water and Wastewater 2012. $\mathrm{pH}$ was measured using HACH pH meter. Dionex ICS-2000 of Ion Chromatography system was used to analyse anions such as phosphate, $\mathrm{PO}_{4}{ }^{3-}(4500-\mathrm{PE})$, total phosphorus, $\mathrm{TP}$ (4500-PE), nitrate, $\mathrm{NO}_{3}{ }^{-}$ $(4500 \mathrm{~B})$ and nitrite, $\mathrm{NO}_{2}^{-}(4500 \mathrm{E})$ in filtered samples. Trace of total suspended solids (TSS) was analysed by filtration standard of APHA $2540 \mathrm{C}$. The organic compounds of chemical oxygen demand (COD) was followed APHA 5220 D procedure and digested using COD reactor of HACH DRB 200 for 2 hours before undergoes titration method on samples. Tests of oil and grease (O\&G) concentration were measured according to modified APHA 5520B using extraction followed byevaporation method. The determination of alkalinity on raw samples were analysed using titration method of APHA 2320 B. The concentration of anionic surfactants experimented was modified from APHA 5540 C, Methylene Blue Absorbing Substances (MBAS). Cationic dye of Methylene blue (MB) formed complex with AR grade: Sodium Luryl Sulphate (SLS), EMORY of MW: $288.38 \mathrm{~g} / \mathrm{mol}$. The results gives the colour intensity of chloroform layer, measured by absorbance, at $\lambda \mathrm{max}=652$ $\mathrm{nm}$. A series of SLS stock solution ranges within $0.5 \mathrm{mg} / \mathrm{L}-5 \mathrm{mg} / \mathrm{L}$ were prepared, as a calibration curve graph. All the measurement of the absorbance were obtained from the spectrophotometer (Model: UV-VIS Scanning Spectrophotometer: Spectro UV-2650 by Labomed). All samples determination were done in triplicate homogenious sample.

\section{Results and Discussion}

Table 2 present the results of the characterization for the eight samples collected at each stations. Overall, station 3 reported the highest concentrations of $\mathrm{PO}_{4}{ }^{3-}, \mathrm{TP}, \mathrm{O} \& \mathrm{G}$, TSS and COD (on average, $10.180 \pm 0.87 \mathrm{mg} / \mathrm{L} \mathrm{PO}_{4}{ }^{3-}, 30.933 \pm 0.31 \mathrm{mg} / \mathrm{L} \mathrm{TP}, 85 \pm 0.64 \mathrm{mg} / \mathrm{L} \mathrm{O \& G}, 325 \pm 0.6 \mathrm{mg} / \mathrm{L} \mathrm{TSS}, 485 \pm$ $0.33 \mathrm{mg} / \mathrm{L}$ COD and $54 \pm 2.5 \mathrm{mg} / \mathrm{L}$ surfactant as MBAS compared to other stations. However, no determination of surfactant (as MBAS) was conducted in Station 2 due to unavailability of samples during the sampling time.

Surfactant was found in greater concentration (as MBAS) at Station 3 more than Station 1 due to the uses of greater nozzles hoses of foams that were applied during washing cars which yielded more foams containing surfactant. Historically, most car wash cleaning products based on detergents, containing mild alkalis [6]. However, as the global car wash industries grew, there had also been improvement on the ingredients compounds of the surfactants used to make cars more clean and shines forced more chemicals being used as the ingredients, resulting greater amount of pollutants being washed away during cleaning. 
Table 2. Pollutant characteristics for accumulation processes for Station 1, Station 2 and Station $3(\mathrm{n}=8)$.

\begin{tabular}{|c|c|c|c|c|c|}
\hline Parameter & Values & Unit & Station 1 & Station 2 & Station 3 \\
\hline \multirow[t]{3}{*}{$\mathrm{pH}$} & $\min$ & \multirow[t]{3}{*}{-} & 7.40 & 7.38 & 7.96 \\
\hline & $\max$ & & 7.88 & 7.90 & 8.33 \\
\hline & mean & & $7.73 \pm 0.85$ & $7.43 \pm 0.37$ & $8.20 \pm 1.66$ \\
\hline \multirow[t]{3}{*}{ Phosphate $\left(\mathrm{PO}_{4}{ }^{3-}\right)$} & $\min$ & \multirow[t]{3}{*}{$\mathrm{mg} / \mathrm{L}$} & 0 & 0 & 8.35 \\
\hline & $\max$ & & 2.31 & 3.48 & 10.23 \\
\hline & mean & & $2.02 \pm 1.4$ & $3.40 \pm 2.05$ & $10.18 \pm 0.87$ \\
\hline \multirow{3}{*}{$\begin{array}{l}\text { Total phosphorus } \\
\text { (TP) }\end{array}$} & $\min$ & \multirow[t]{3}{*}{$\mathrm{mg} / \mathrm{L}$} & 0 & 0 & 25.6 \\
\hline & $\max$ & & 7.09 & 10.66 & 33.70 \\
\hline & mean & & $7.05 \pm 2.2$ & $9.40 \pm 1.55$ & $30.93 \pm 0.31$ \\
\hline \multirow{3}{*}{$\begin{array}{l}\text { Oil and grease } \\
(\mathrm{O} \& \mathrm{G})\end{array}$} & $\min$ & \multirow[t]{3}{*}{$\mathrm{mg} / \mathrm{L}$} & 55 & 78 & 79 \\
\hline & $\max$ & & 62 & 86 & 89 \\
\hline & mean & & $68.0 \pm 0.4$ & $80.0 \pm 0.3$ & $85.0 \pm 0.6$ \\
\hline \multirow[t]{3}{*}{ Alkalinity (Alk) } & $\min$ & \multirow[t]{3}{*}{$\mathrm{mg} / \mathrm{L}$} & 0 & 0 & 108 \\
\hline & $\max$ & & 23.12 & 34.77 & 300 \\
\hline & mean & & $21.53 \pm 0.64$ & $31.94 \pm 1.22$ & $293.00 \pm 0.12$ \\
\hline \multirow[t]{3}{*}{ Nitrate $\left(\mathrm{NO}_{3}^{-}\right)$} & $\min$ & \multirow[t]{3}{*}{$\mathrm{mg} / \mathrm{L}$} & 0 & 0 & 2.16 \\
\hline & $\max$ & & 0.40 & 0.42 & 2.57 \\
\hline & mean & & $0.29 \pm 0.58$ & $0.36 \pm 0.76$ & $2.86 \pm 0.25$ \\
\hline \multirow{3}{*}{ Nitrite $\left(\mathrm{NO}_{2}^{-}\right)$} & $\min$ & \multirow[t]{3}{*}{$\mathrm{mg} / \mathrm{L}$} & 0 & 0 & 0 \\
\hline & $\max$ & & 0.15 & 0.19 & 0.01 \\
\hline & mean & & $0.13 \pm 0.31$ & $0.15 \pm 0.47$ & $0.01 \pm 0.72$ \\
\hline \multirow{3}{*}{$\begin{array}{l}\text { Total suspended } \\
\text { solid (TSS) }\end{array}$} & $\min$ & \multirow[t]{3}{*}{$\mathrm{mg} / \mathrm{L}$} & 56 & 95 & 268 \\
\hline & $\max$ & & 89 & 104 & 333 \\
\hline & mean & & $85.00 \pm 1.20$ & $100.00 \pm 0.62$ & $325.00 \pm 0.6 .00$ \\
\hline \multirow{3}{*}{$\begin{array}{l}\text { Chemical oxygen } \\
\text { demand (COD) }\end{array}$} & $\min$ & \multirow[t]{3}{*}{$\mathrm{mg} / \mathrm{L}$} & 89 & 180 & 398 \\
\hline & $\max$ & & 210 & 266 & 490 \\
\hline & mean & & $190.0 \pm 1.00$ & $232.0 \pm 0.6$ & $485.0 \pm 0.3$ \\
\hline \multirow{3}{*}{$\begin{array}{l}\text { Surfactant (as } \\
\text { MBAS) }\end{array}$} & $\min$ & \multirow[t]{3}{*}{$\mathrm{mg} / \mathrm{L}$} & 7.75 & \multirow[t]{3}{*}{-} & 51.20 \\
\hline & $\max$ & & 33.16 & & 60.50 \\
\hline & mean & & $17.90 \pm 8.09$ & & $54.00 \pm 2.50$ \\
\hline
\end{tabular}

For other parameters in Station 3, slightly alkaline $\mathrm{pH}$ of $8.20 \pm 1.66$, low concentration of $\mathrm{NO}_{3}{ }^{-}$ $(2.860 \pm 0.25 \mathrm{mg} / \mathrm{L})$ and $\mathrm{NO}_{2}^{-}(0.009 \pm 0.72 \mathrm{mg} / \mathrm{L})$ were within the typical ranges found in the industrial effluents of standard B. For comparison purposes, the mean concentration of contaminant levels reported for COD shows concentration within range of $75 \mathrm{mg} / \mathrm{L}-738 \mathrm{mg} / \mathrm{L}$ [4]. The results revealed that the concentration of car washes for different car washes have greater COD, and most of the time exceeded the Standard B in environmental regulations $(200 \mathrm{mg} / \mathrm{L}$ of COD) with Station 1 $(190 \pm 1.00 \mathrm{mg} / \mathrm{L})$, Station $2(232 \pm 0.59 \mathrm{mg} / \mathrm{L})$, and Station $3(485 \pm 0.33 \mathrm{mg} / \mathrm{L})$. Generally, COD comes from the use of non biodegradable surfactant with dirts during car washing [4]. The permissible limit of Malaysia Effluent Discharge Standards of Standard B for O\&G, is $10 \mathrm{mg} / \mathrm{L}$. In this study O\&G at all stations have exceeded the permissible limit in three stations, where Station 1 recorded (68 $\pm 0.42 \mathrm{mg} / \mathrm{L})$, Station $2(80 \pm 0.31 \mathrm{mg} / \mathrm{L})$, and Station $3(85 \pm 0.64 \mathrm{mg} / \mathrm{L})$, above the ranges of standard regulation. The results indicated the different types of car wash stations are not the determinant in the variation of oil and grease that was observed. The age of equipment, type and concentration of cleaning solutions, size of separation tanks, and time since last emptied could all have contributed to the differences observed in the $O \& G$ concentrations [7]. Whereas, the concentration of $\mathrm{NO}_{3}{ }^{-}$and $\mathrm{NO}_{2}{ }^{-}$were not considered as major pollutants to environments, since the ranges detected by all the car wash stations below the detection limit of standard $\mathrm{B}, 50 \mathrm{mg} / \mathrm{L}$. The elevated concentrations of TSS for Station $2(100 \pm 0.62 \mathrm{mg} / \mathrm{L} \mathrm{TSS})$ and Station $3(325 \pm 0.6 \mathrm{mg} / \mathrm{L}$ TSS) were above the limit of $100 \mathrm{mg} / \mathrm{L}$ TSS regulated for standard B. The results of the higher TSS could be from the tire dust, rust stain, dirt, films from brakes, and grimes being washed away during cleaning processes. 
Among the three car wash stations, Station 1 was the one that can be collected the samples and differentiate between stage processes of pre soak, wash and rinses. From Table 3, $\mathrm{PO}_{4}{ }^{3-}(3.00 \pm 1.22$ $\mathrm{mg} / \mathrm{L})$ and TP $(8.88 \pm 2.0 \mathrm{mg} / \mathrm{L})$ were higher during the washing process. The pollutants could be come from the dirt washed off vehicles, nature and concentration of contaminants with the chemicals and procedures used in the wash process during car wash activities $[4,5]$. In this study, the TSS concentration for wash processes $(90.00 \pm 0.76 \mathrm{mg} / \mathrm{L})$ was slightly near to the range of standard $\mathrm{B}$, $100 \mathrm{mg} / \mathrm{L}$. High amount of TSS were being washed away during washing process in removing the dirts and grimes on body parts and tire of cars. For COD, the values were complying with the regulation standard $\mathrm{B}$ for pre soak, wash and rinse processes. Based on the results of the characterization, the pollutant mean for O\&G during pre soak $(79.0 \pm 1.10 \mathrm{mg} / \mathrm{L})$, wash $(50.0 \pm 0.38$ $\mathrm{mg} / \mathrm{L})$ and rinse $(18.0 \pm 1.26 \mathrm{mg} / \mathrm{L})$ does not meet with standard $\mathrm{B}$ regulation. However, the higher concentration was generated by the pre soak process since it was washed away together with the crude oil and lubricating oil comes from motor oil of car wash stations or might the leaking of engine parts resulting high amount of O\&G were detected [10].

Table 3. Pollutant characteristics for different stages processes for Station 1.

\begin{tabular}{|c|c|c|c|c|c|}
\hline Parameter & Values & Unit & Pre-soak & Wash & Rinse \\
\hline \multirow[t]{3}{*}{$\mathrm{pH}$} & $\min$ & & 7.48 & 7.80 & 7.96 \\
\hline & $\max$ & & 7.80 & 7.98 & 7.99 \\
\hline & mean & & $7.59 \pm 0.55$ & $7.81 \pm 0.99$ & $7.60 \pm 0.53$ \\
\hline \multirow[t]{3}{*}{ Phosphate $\left(\mathrm{PO}_{4}{ }^{3-}\right)$} & $\min$ & \multirow[t]{3}{*}{$\mathrm{mg} / \mathrm{L}$} & 0.00 & 0.35 & 0.13 \\
\hline & $\max$ & & 0.89 & 3.55 & 2.60 \\
\hline & mean & & $0.41 \pm 1.23$ & $3.00 \pm 1.22$ & $2.00 \pm 1.80$ \\
\hline \multirow[t]{3}{*}{ Total phosphorus (TP) } & $\min$ & \multirow[t]{3}{*}{$\mathrm{mg} / \mathrm{L}$} & 0.00 & 0.98 & 0.93 \\
\hline & $\max$ & & 2.35 & 9.33 & 6.93 \\
\hline & mean & & $2.09 \pm 1.32$ & $8.88 \pm 2.0$ & $5.57 \pm 1.08$ \\
\hline \multirow[t]{3}{*}{ Oil and grease $(\mathrm{O} \& \mathrm{G})$} & $\min$ & \multirow[t]{3}{*}{$\mathrm{mg} / \mathrm{L}$} & 64.00 & 31.00 & 20.00 \\
\hline & $\max$ & & 96.00 & 59.00 & 29.00 \\
\hline & mean & & $79.00 \pm 1.10$ & $50.00 \pm 0.38$ & $18.00 \pm 1.26$ \\
\hline \multirow[t]{3}{*}{ Alkalinity (Alk) } & $\min$ & \multirow[t]{3}{*}{$\mathrm{mg} / \mathrm{L}$} & 0.00 & 18.80 & 9.21 \\
\hline & $\max$ & & 22.00 & 25.56 & 19.68 \\
\hline & mean & & $20.00 \pm 1.53$ & $23.00 \pm 0.20$ & $18.50 \pm 1.31$ \\
\hline \multirow[t]{3}{*}{ Nitrate $\left(\mathrm{NO}_{3}{ }^{-}\right)$} & $\min$ & \multirow[t]{3}{*}{$\mathrm{mg} / \mathrm{L}$} & 0.00 & 0.41 & 0 \\
\hline & $\max$ & & 0.40 & 1.59 & 1.61 \\
\hline & mean & & $0.30 \pm 1.09$ & $1.23 \pm 1.22$ & $1.45 \pm 1.10$ \\
\hline \multirow[t]{3}{*}{ Nitrite $\left(\mathrm{NO}_{2}^{-}\right)$} & $\min$ & \multirow[t]{3}{*}{$\mathrm{mg} / \mathrm{L}$} & 0 & 5.8988 & 6.76 \\
\hline & $\max$ & & 0.009 & 6.146 & 7.230 \\
\hline & mean & & $0.002 \pm 0.260$ & $4.905 \pm 0.640$ & $5.981 \pm 0.930$ \\
\hline \multirow{3}{*}{$\begin{array}{l}\text { Total suspended solid } \\
\text { (TSS) }\end{array}$} & $\min$ & \multirow[t]{3}{*}{$\mathrm{mg} / \mathrm{L}$} & 75.00 & 89.00 & 44.00 \\
\hline & $\max$ & & 97.00 & 100.00 & 52.00 \\
\hline & mean & & $80.99 \pm 1.10$ & $90.00 \pm 0.76$ & $36.00 \pm 1.25$ \\
\hline \multirow{3}{*}{$\begin{array}{l}\text { Chemical oxygen } \\
\text { demand (COD) }\end{array}$} & $\min$ & \multirow[t]{3}{*}{$\mathrm{mg} / \mathrm{L}$} & 68.0 & 71.0 & 32.0 \\
\hline & $\max$ & & 126.0 & 192.0 & 75.0 \\
\hline & mean & & $100.0 \pm 1.5$ & $166.0 \pm 1.8$ & $48.50 \pm 0.3$ \\
\hline
\end{tabular}




\section{Conclusion}

The car wash stations were analyzed regarding the characterization of car wash wastewaters with parameter of $\mathrm{pH}, \mathrm{PO}_{4}{ }^{3-}, \mathrm{TP}, \mathrm{O} \& \mathrm{G}, \mathrm{Alk}, \mathrm{TSS}, \mathrm{NO}_{3}{ }^{-}, \mathrm{NO}_{2}{ }^{-}, \mathrm{COD}$, and surfactant as MBAS. The characteristics of car wash wastewater discharges was dependent on the type of car washes. Snow foam car wash station, Station 3 presents the high concentration of pollutants due to the greater foam of surfactants. It yields high concentration of $\mathrm{PO}_{4}{ }^{3-}, \mathrm{TP}, \mathrm{O \& G}, \mathrm{TSS}$, and COD where the values were above the permissible limit of effluent standard B and not safe to be discharged to water body. The characterization between different phases of car washing processes including of pre soak, wash and rinse processes of Station 1 have been characterized. The high concentrations were obtained for $\mathrm{PO}_{4}{ }^{3-}$, TP, TSS and COD (wash), $\mathrm{NO}_{3}{ }^{-}$and $\mathrm{NO}_{2}{ }^{-}$in (pre soak), and O\&G in (pre soak, wash and rinse) processes. All the parameters were following the permissible limit of standard B, except for the concentration of O\&G.

\section{Acknowledgement}

This work is funded by University Tun Hussein Onn Malaysia of Postgraduate Incentive Research Grant (GIPS), Vot No. 1404.

\section{References}

[1] K. Boussu, C. Kindts, C. Vandecasteele and B.V.D. Bruggen, Applicability of nanofiltration in the carwash industry, Separation and Purification Technology, 54, 139-146, (2007).

[2] B.S. Shete and N.P. Shinkar, Use of membrane to treat car wash wastewater, Int. J. of Research in Science and Advanced Technologies, 3(1), 13-19, (2014).

[3] J. Perkowski, S. Bzdon, A. Bulska and W.K. Jozwiak, Decomposition of detergents present in car-wash sewage by titania photo-assisted oxidation, Polish J. of Environmental Studies, 15(3), 457-465, (2006).

[4] W.J. Lau, A.F. Ismail and S. Firdaus, Car wash industry in Malaysia: Treatment of car wash effluent using ultrafiltration and nanofiltration membranes, Separation and Purification Technology, 104, 26-31, (2013).

[5] F.K. Abagale, D.A. Sarpong, J.O. Ojediran, R. Osei-Agyemang, A.G. Shaibu and P.T. Birteeb, Heavy metal concentration in wastewater from car washing bays used for agriculture in the Tamale Metropolis, Ghana, Int. J. of Current Research, 5(6), 1571-1576, (2013).

[6] H.C. Genuino, N.N. Opembe, E.C. Njagi, S. McClain and S.L. Suib, A Review of hydrofluoric acid and its use in the car wash industry, J. of Industrial and Engineering Chemistry, 18, 15291539, (2012).

[7] C. Brown, Water effluent and solid waste characteristics in the professional car wash industry, Int. Car Wash Association, Toronto, (2002).

[8] A. Al-Odwani, A. Ahmed and S.B. Hamad, Carwash water reclamation in Kuwait, Desalination, 206(1-3), 17-28, (2007).

[9] J. Oknich, Handbook for the Perceived Environmental Impact of Car Washing, RamseyWashington Metro Watershed District, Washington, (2002).

[10]R.S. Rao, C.P. Jyothi, R.S. Prakasham, P.N. Sarma and L.V. Rao, Xylitol production from corn fiber and sugarcane bagasse hydrolysates by Candida tropicalis, Bioresource Technology, 97(15), 1974-1978, (2006). 